\title{
СОЦИАЛЬНЫЕ АСПЕКТЫ ИСТОРИИ ФОРСИРОВАННОГО РАЗВИТИЯ ИНДУСТРИАЛЬНОГО КОМПЛЕКСА УРАЛА В 20-30-Е ГГ. ХХ ВЕКА
}

\section{SOCIAL ASPECTS FORCED DEVELOPMENT STORIES URAL INDUSTRIAL COMPLEX IN THE 20-30S. XX CENTURY}

\section{Lavrova M. Arakelyan}

Summary: On the basis of archival materials, the article examines the economic and social aspects of the accelerated development of the industrial complex in the Urals, during the first five-year plans. The analysis of the regulatory framework is carried out. The article contains a number of previously unpublished sources.

Keywords: industrialization, collectivization, migration, food supply, Magnitstroy, Uralmashstroy, labor settlers, special contenders, peasantry.
, Лаврова Ирина Анатольевна

К.и.н., дочент, ФГБВОУ ВО «Академия гражданской защиты M4C Poccuu»

iralavrova@mail.ru

Аракелян Марина Александровна,

К.и.н., дочент, ФГБВОУ ВО «Академия гражданской защиты MЧC Poccuu»

koschka_1881@mail.ru

Аннотация: В статье на основании архивных материалов рассмотрены экономические и социальные аспекты форсированного развития индустриального комплекса на Урале, времен первых пятилеток. Проведен анализ нормативно-правовой базы. В статье приведен ряд ранее неопубликованных источников.

Ключевые слова: индустриализация, коллективизация, миграция, продовольственное обеспечение, Магнитстрой, Уралмашстрой, трудопоселенцы, спецконтенгент, крестьянство.
$\mathrm{B}$ Советском Союзе с конца 1920-х - начало 1930-х годов наблюдается огромный рост промышленного производства, все это происходит на фоне «великой депрессии», мирового экономического кризиса и конечно этот рост был очень убедительным аргументом в пользу социализма, но было ли все так гладко? В действительности, проходившее в СССР «социалистическое наступление», поставило под полный государственный контроль все сферы жизни общества и повлекло за собой не только невиданные достижения, но и страшные лишения и трудности.

Мощный индустриальный комплекс на Урале создавался ценой нечеловеческих усилий. Форсированная индустриализация привела к стремительному росту уральских городов, многие из которых до этого были лишь небольшими поселками. Расширение промышленного производства и недостаток местных технических кадров привели к миграции рабочей силы из сельских районов региона и страны. Результатом этого процесса стало увеличение численности городского населения. Наиболее значительным рост был в первой половине 1930-х годов, особенностью молодых промышленных центров являлось неразвитость социальной инфраструктуры. Крупное индустриальное строительство требовало огромных капиталовложений и осуществлялось за счет снижения жизненного уровня населения.

Стремление максимально быстрыми темпами и с минимальными затратами создать ряд важнейших произ- водств привело к резкому отставанию всей социальной сферы. Особенно тяжелое положение складывалось на многочисленных индустриальных стройках Урала. Строительство велось в большинстве случаев без проведения предварительной работы по созданию необходимой инфраструктуры. На будущую строительную площадку прибывал своеобразный трудовой десант, живший буквально под открытым небом. Во многом это объяснялось положением использовавшейся рабочей силы. Строительство большинства промышленных предприятий осуществлялось силами так называемого «спецконтингента», куда входили заключенные исправительно-трудовых лагерей (ИТЛ), трудпоселенцы, спецпоселенцы.

В 1930-е годы оформилась индустриальная база, которая на десятилетия вперед определившая направление развития Уральского региона. Но реализация амбициозных планов советского правительства сопровождалась трагедией миллионов людей. Информатор Уваров сообщил плановому отделу Челябтракторостроя о состоянии жилищного строительства (28 сентября 1930 года): «Обращаю внимание на постройку землянок на 7-м участке и отделом снабжения для рабочих трепелевого завода. На 7-м участке на выстроенные 2 землянки употреблен лес из самых последних лесных отбросов и т.д., причем полов в общей землянке совершенно нет. Печи устанавливаются железные, что создает, если затопят печи, невозможный воздух». Статья в газете «Челябинский рабочий» красноречиво называлась «Женщин - на поля! Мужчин - на новостройки».[1] 
Жертвами «индустриальной гонки» стало и многострадальное крестьянство, за счет ограбления которого и были во многом достигнуты индустриальные высоты, ставшие гордостью Урала.

По темпам коллективизации крестьянских хозяйств Урал опережал другие регионы. Осенью и зимой 1929 года колхозное движение нарастало по всей стране благодаря нажиму партийных органов. Под влиянием репрессивных мер к 1 марта 1930 года процент коллективизации в Уральской области вырос до 68,8\%.

В ходе сплошной коллективизации шла ликвидация кулачества. По решению бюро Уралобкома ВКП(б) от 5 февраля 1930 года «О ликвидации кулацких хозяйств в связи с массовой коллективизацией» было установлено ликвидировать 20 тысяч хозяйств. Каждый район Урала получил так называемую «контрольную цифру» ликвидации кулачества. Кулаков, зачисленных в первую и вторую категории, предполагалось выселить в северные и восточные районы страны, третью категорию расселить в труднодоступных местах в пределах своего района или округа на худшие земли. В число раскулаченных часто попадали не только зажиточные крестьяне, но и середняки, и даже бедняки, причисленные к «подкулачникам», к ним относили тех, кто высказывался против коллективизации и раскулачивания. К июлю 1930 года в Уральской области было раскулачено более 30 тысяч крестьянских хозяйств, что значительно превышало советской властью. Жертвами раскулачивания оказывались и крестьянские дети, выселяемые вместе с родителями.

Для ускоренных темпов индустриализации, которая проходила в стране одновременно с коллективизацией нужны были значительные трудовые ресурсы. Переселенцы являлись дешевой рабочей силой на самых тяжелых участках производства. Они быстро погибали, но тут же заменялись новой массой людей. Поэтому процесс репрессирования был необходим государству и носил непрерывный характер. Для экономики страны в целом крестьянская ссылка являлась тяжелым бременем, не говоря уже о трагических судьбах огромного количества людей.

Ускоренное наращивание экономического потенциала восточных районов страны вызвало с конца 1920-х—1930-е годов невиданные ранее массовые перемещения населения, как добровольные, так и принудительные. Насильственная трудовая миграция вплоть до начала Великой Отечественной войны являлась основным источником рабочей силы. Первая мощная волна переселенцев была связана с началом раскулачивания. Только за 1930-1931 годы на Урал было выслано 128 тысяч семей (это более одной трети от общего числа раскулаченных спецпереселенцев по стране). Численность спецпереселенцев на территории Уральской области достигала по оценкам различных исследователей от 564 до 573 тыс. человек. Основным источником принудительных мигрантов являлись Украина (25\%) и Северный Кавказ (20,3\%). [2. С. 3]

В период между переписями населения 1926-1937 годов население Свердловской области (в сопоставимых границах 1937 года) выросло на 973 тыс. человек (на $30,9 \%)$.

Форсированная индустриализация вызвала рост городского населения Урала, приток сельского населения в города. Количество городского населения увеличилось на 1227,1 тыс. человек (145,8\%), а сельского - уменьшилось на 363,9 тыс. человек (15,7\%). Социально-демографические процессы, проходившие в регионе обусловили тенденции динамики численности населения. На демографические процессы в стране в эти годы повлияли неурожайный 1936 года и развернувшиеся репрессии. Доля городского населения в 1937 года поднялась до 52,2\% от всего населения области, а сельского - упала до 47,8\% т.е. большая часть населения проживала в городах.

Главной формой привлечения рабочей силы в промышленность в конце 1920-х-1930-х годов был так называемый организованный набор. Источником обеспечения нужд промышленности, особенно строительства, было крестьянство. Материалы профсоюзной переписи, проведенной в 1932-1933 годах, показывают, что практически во всех отраслях экономики Урала более половины занятых составляли выходцы из крестьян. Большая часть из них сохраняли свою связь с деревней. [3.С.96151]

До конца 1920-х годов приток крестьян на стройки осуществлялся через биржи труда, путем заключения индивидуальных договоров, а также стихийно - самотеком. Как показывают источники, последняя форма преобладала именно на Урале. Так, более половины строителей Уралмашстроя и Челябтракторстроя прибыли на стройки самостоятельно. [4.]

По сведениям областной Рабоче-крестьянской инспекции из колхозов Уральской области на новостройки, в промышленность за 1931 год ушло 301,1 тыс. человек, что составило 18,7\% к общему числу трудоспособных. Часть крестьян бежали из деревни, не желая оставаться в колхозах, поскольку отходничество позволяло не возвращаться в деревню. К маю 1932 года на заводы Востокстали прибыло 10,1 тыс. человек из деревень, из них осталось на постоянную работу 3,3 тыс. человек. На Магнитострой в 1932 году было завербовано 9,8 тыс. человек, а самотеком прибыло 13,3 тыс. человек. 
В ходе коллективизации фиксировалось массовое бегство крестьян из деревни. Например, за зиму 19301931 годах в Троицком округе покинуло село 1400 семей. Из 45957 обобществленных хозяйств на 20 марта 1930 года выбыло 23506, то есть более половины.[5]

В 1932 году отток крестьян из деревни усилился, чтобы остановить неуправляемое бегство из деревни, а причиной массового бегства стал вспыхнувший голод, и попытаться направить самотек в «нужное русло», было принято постановление ЦИК и СНК СССР «О порядке отходничества из колхозов» от 17 марта 1933 года по этому постановлению отходниками теперь начали считаться лишь те граждане, которые заключили договор с хозяйственной организацией.[6. С.168]

Ещё одной мерой, призванной оградить города от наплыва самовольных переселенцев, стало введение в начале 1933 года паспортной системы с обязательной пропиской по месту жительства. Однако это не уменьшило масштабы бегства крестьян из деревни. 21 июня 1938 года было принято постановление СНК СССР «Об упорядочении дела набора рабочей силы из колхозов», в котором отмечало, что учет отходников поставлен из рук вон плохо и в ряде колхозов Свердловской области ощущается нехватка рабочих рук. С 1 сентября 1939 года Комиссия по организованному набору рабочей силы могла производить мобилизацию крестьян только для нужд строительства, лесозаготовок, угольной, торфяной и рудной промышленности, рыбных промыслов и сахарных заводов.

Коллективизация вынудила многих крестьян подняться с насиженных мест и отправляться в города в поисках лучшей доли. Низкие результаты производственной деятельности также приводили к бегству из колхозов. За 1931 год в промышленность ушло порядка 438,2 тыс. крестьян Уральской области. За первый квартал 1932 года из деревень бежало порядка 62,3 тыс. семей. Чтобы остановить массовое бегство из деревни, руководство страны запрещает местным органам управления выдавать сельским жителям паспорта, без которых не возможно было устроиться на работу.

Угрозами и обещаниями крестьяне были загнаны в артели, главной целью которых были совместный труд и продажа продуктов не на рынок, а государству. Тем самым было ликвидировано право крестьянина на самостоятельное ведение хозяйства, также крестьянин терял право распоряжаться продукцией своего труда. Был изменен подход государства и к поставкам. Из обычного налога - части дохода, изымаемой в пользу государства, поставки превращались в священный долг, первоочередную обязанность, главную заповедь. Бил учрежден и новый порядок распределения зерна: в первую очередь зерно поставлялось государству, если останется шло в семенные фонды, если и после этого что-то сохранялось, то это шло на корм скоту и питание колхозников в период полевых работ, наконец, в самую последнюю очередь зерно выдавалось на трудодни самим колхозникам.

Хлебозаготовки стали проблемой номер один с начала существования колхозов, те планы, которые спускались сверху не учитывали положения на местах и были мало выполнимы. Валовая продукция зерновых в колхозах Урала в 1931 года составила 10999 тыс. центнеров, а план хлебозаготовок по телеграмме Сталина и Молотова был установлен в 5476 тыс. центнеров, увеличенный позже до 7625 тыс. центнеров. Это привело к тому, что многие колхозы не смогли выдать крестьянам зерно по трудодням, в результате этого возникло тяжелейшее положение с продовольствием, что вынудило правительство в конце 1931 года возвратить Уральской области 3479 тыс. центнеров зерна в виде ссуды. [7. С. 75-82]

Посевная кампания 1932 года закончилась только к июлю, а уборка урожая хлебов затянулась до конца октября, что привело в конечном итоге к гибели части посевов, ушедших под снег. В результате с осени 1932 года по весну 1933 года в деревне разыгралась трагедия с хлебозаготовками. Во все районы были посланы уполномоченные обкома ВКП(б) и специальные комиссии. Практически был забран весь собранный хлеб, в некоторых районах были изъяты даже семенные фонды. Те колхозы и колхозники, которые не выполнили план, объявлялись «саботажниками хлебосдачи». К ним применялись меры воздействия - прекращение подвоза товаров и полное прекращение кооперативной и частной торговли, проводилась чистка аппаратов колхозов, изъятие органами ОГПУ «контрреволюционных элементов».

7 августа 1932 года ЦИК и СНК СССР приняли постановление «Об охране имущества государственных предприятий, колхозов и кооперации и укреплении общественной (социалистической) собственности». В народе он получил название «Указ семь - восемь», «Закон о трех колосках» или «закон семь восьмых». По этому постановлению предусматривались самые суровые наказания за «хищение» (воровство) колхозного имущества даже в минимальных размерах. На основании постановления от 7 августа 1932 года граждане, подбиравшие колоски на колхозном поле, объявлялись «расхитителями колхозной собственности» и могли получить срок не ниже 10 лет лишения свободы. С 1935 года закон применялся уже к детям с 12-летнего возраста. По закону от 23 августа 1932 года. «О борьбе со спекуляцией» за продажу продуктов сельского хозяйства следовало лишение свободы от 5 до 10 лет. При этом законодательство не делало различия между голодающими и спекулянтами. В условиях недоедания и голода на Урале наблюдались кражи хлеба из колхозов, сбор колосьев на колхозных полях. За июль-сентябрь 1933 года по делам о хищениях 
в Уралобласти было осуждено более 3 тысяч колхозников, большой процент осужденных составляли женщины и подростки. В 1934 года только по Челябинской области за это же было отдано под суд 9100 человек. [8. С.25]

Голод 1932-1933 годов явился результатом курсом так называемого «большого скачка», поскольку изъятие хлеба в колхозах производилось в целях выполнения нереальных, произвольно установленных заданий индустриального развития. Удельный вес заготовок в общем объеме валового производства сельскохозяйственных продуктов в Уральской области поднялся по зерновым с 15\% в 1928 года до 45\% в 1932 году, по мясу соответственно - с 16 до 58\%.

По данным бюджетных обследований крестьянских семей Уральской области суточная норма питания на одного человека в августе 1932 года составила 464 г хлебасуррогата, 425 г картофеля, 377 г молока, 125 г овощей, 5,1 г мясопродуктов, 8,7 г рыбы, 0,08 шт. яиц.

Как видно, основным источником питания были картофель, хлеб-суррогат и менее двух стаканов молока. В 1933 году колхозы не смогли выделить колхозникам даже минимум зерна. До 1 килограмма на трудодень смогли выделить всего 36\% колхозов Свердловской области, от 1,1 до 3,6 кг - 52\% колхозов. В Челябинской области за 1933 год на трудодень колхозникам выдали по 507 грамм зерна, 411 грамм картофеля и 30 копеек денег.

В ходе массовой коллективизации крестьяне, оказавшиеся в колхозах, фактически лишились не только своей собственности, но и приусадебных участков и хозяйств. В 1932 году ситуация с приусадебными участками немного улучшилась, и хотя размер огородов на Урале не превышал 6 соток, все-таки семья колхозника имела возможность частично обеспечить себя картофелем и овощами. На 1 января 1933 года только 55\% колхозников Урала имели в индивидуальном пользовании посевы, $61 \%$ держали крупный рогатый скот в том числе коров - 57\%), 6,2\% - свиней, 38\% - овец и коз. [107] Таким образом, половина колхозников существовала за счет того, что выделит колхоз.

Возникшие в связи с чрезмерным изъятием сельскохозяйственной продукции в ходе заготовительных кампаний продовольственные затруднения обернулись для сельского населения голодом 1932-1933 годов. Голод сопровождали серьезные эпидемии сыпного и брюшного тифа, цинги, известны факты антропофагии, трупоедства, употребления в пищу кошек и собак, самоубийств на почве голода. Убыль населения Уральской области в 1933 году составила 7,2\% от убыли населения РСФСР. За восемь месяцев - с декабря 1932 года по август 1933 года- количество смертей в Уральской области выросло более чем в 2,5 раза. [8. С.96]
Проводившаяся ускоренными темпами, коллективизация стала главной причиной аграрного кризиса первой половины 1930-х годов. Не продуманная, мало выполнимая заготовительная политика советского государства обусловила наступление продовольственных затруднений. В условиях аграрного кризиса и роста городского населения, связанного с индустриальным развитием региона, нормированное распределение, карточная система снабжения не смогли стабилизировать продовольственную ситуацию. Главными особенностями механизма продовольственного обеспечения населения была централизация и дискриминационный характер по отношению к сельскому населению.

Горожанам также приходилось выживать в тяжелейших условиях. В музее истории Уралмашзавода на старых фотографиях запечатлены строители завода, в посконных рубахах, обутые в лапти, вооруженные в основном топорами, лопатами и граблями. Именно благодаря труду этих недавних крестьян за 5 лет был построен один из крупнейших в мире заводов тяжелого машиностроения.

Строители жили в неблагоустроенных бараках и землянках. Каждый барачный поселок («куст», как тогда говорили) имел свое название. Самые первые бараки не имели даже без перегородок. Фактически они представляли собой обычные сараи с печным отоплением и нарами (порой двухэтажными). В этих бараках проживали десятки семей, отделенные друг от друга только ситцевыми занавесками. Согласно заводской статистике в 1933 года в бараках на одного проживавшего приходилось 3,3 кв. м жилой площади.[9. С.147]

Строительство Магнитогорского металлургического комбината проходило не только в сложных климатических условиях, но и в не хватке стройматериалов, продуктов питания, медикаментов, жилья. Согласно статистике за 1933 год жилая площадь на Магнитострое составляла 1,8 кв. м. Удельный вес спецпереселенцев был очень высоким, например на ММК он доходил до 40\%. В январе 1933 года на Магнитострой прибыло 26,7 тысяч осужденных по 58 статье УК РСФСР. Заключенные находились в тяжелейших условиях, получая в день по 100 граммов хлеба, жили в холодных и сырых бараках и землянках, что влекло за собой большую смертность от голода, холода и болезней.[10. С.205]

В течение 1932 года голод набирал силу. Его спровоцировали эпидемии

сыпного и брюшного тифа, натуральной оспы, цинги. В Уралобласти наиболее пораженными сыпным тифом населенными пунктами являлись Свердловск, Магнитогорск, Челябинск, Златоуст, Надеждинск, Пермский и Чердынский районы. В спецсправке Секретно-политиче- 
ского отдела ОПтУ за апрель 1933 года отмечены острые продовольственные затруднения в Челябинском, УстьУйском, Троицком, Камышловском, Багарякском, Бродокалмакском, Ярковском, Бердюжском, Ольховском, Сухоложском, Шадринском и других районах Уралобласти. В справке упоминались случаи трупоедства в ряде районов области, употреблении в пищу кошек и собак и распространении заболеваний на почве голода. В колхозе им. Сталина Михайловского сельского совета Троицкого района трупы павшего от сапа скота, залитого карболовым раствором, растаскивались колхозниками - нацменами и русскими со скотомогильников и употреблялись в пищу. [11.С. 241] В Уралобласти в 1933 года областной прокуратурой были зафиксированы факты каннибализма. [12.]

Аграрный кризис конца 1920-х- начала1930-х годов, рост городского населения, связанных с индустриализацией региона, введенное нормированное распределение продуктов и карточная система не смогли предотвратить продовольственный кризис и голод.

Уральская область из района страны, который сам себя полностью обеспечивал зерновыми культурами, превратился в район, требующий ввоза зерновых.

Одним из главных особенностей продовольственного обеспечения населения стали, централизация и дискриминализация по отношению к сельскому населению.

Модернизация продовольственного обеспечения, полностью изменила общепринятые нормы и структуры потребления.

В СССР в 1920-х - 1930-х годах в механизме продовольственного обеспечения страны, огромную роль играло государство, которое выступило в качестве организатора производства и распределителя продовольственных ресурсов.

Система государственного централизованного снабжения городского населения в условиях продовольственных кризисов, созданная в СССР в период активного промышленного освоения не смогла справится с задачей бесперебойного обеспечения продовольствием населения, что в результате привело к серьезным демографическим потерям.

1. Челябинский рабочий. 1931. 8 февраля.

\section{ЛИТЕРАТУРА}

2. Земсков В.Н. Спецпереселенцы (по документам НКВД СсСР) // Социологические исследования.1990.№ 11. С.3-12

3. Профсоюзная перепись 1932-1933. Статистический отдел. М., 1934. С. 96-151.

4. Государственный архив Свердловской области (ГАСО). Ф. р-245. Оп. 1. Д.400. Л. 18.

5. Государственный архив Свердловской области (ГАСО). Ф. р-245. Оп.2. Д.13. Л.17; Д.182. Л. 6-42

6. Официальный сборник важнейших законов правительства, постановлений и распоряжений Уральского областного исполнительного комитета. Свердловск, 1931.с.59.

7. К Корнилов Г.Е. Продовольственное обеспечение стратегий хозяйственного освоения восточных районов и социально-демографические последствия её реализациив 1890-е-1930-е годы.//XVII Всероссийские историко-педагогические чтения: сб. науч. ст. / ФГБОУ ВПО «Урал. гос. пед. ун-т», Ин-т истории и археологии Ур0 РАН. Екатеринбург, 2013. Часть ІІ. С. 75-82

8. Баранов Е.Ю. Аграрное производство и продовольственное обеспечение населения Уральской области в 1928—1933 гг: дис. ... канд. ист. наук: 07.00 .02 / Баранов Евгений Юрьевич. - Екатеринбург, 2002. - 228 с.

9. Агеев С.С. Отец заводов// Урал в панораме XX века. Ин-т истории и археологии Ур0 РАН. Екатеринбург, 2005.С.247-254

10. Баранов Е.Ю. Аграрное производство и продовольственное обеспечение населения Уральской области в 1928 — 1933 гг: дис. .... канд. ист. наук: 07.00 .02 / Баранов Евгений Юрьевич. - Екатеринбург, 2002. - 228 с

11. Бердель А.Э. Символ социализма// Урал в панораме XX века. Ин-т истории и археологии УрО РАН. Екатеринбург, 2004. С. 241-253

12. Музей истории ГУВД Свердловской области. Коллекция документов. Папка 1930-е годы. 